\title{
Analisis Aspek Biologis dan Psikologis Ibu terhadap Stunting pada Balita Keluarga Miskin di Kota Palembang
}

\author{
Uttami A. Suca ${ }^{1}$, Nur Alam Fajar ${ }^{2}$, Haerawati Idris ${ }^{3}$ \\ Magister Program Studi Ilmu Kesehatan Masyarakat, Universitas Sriwijaya ${ }^{1,2,3}$ \\ uttami.suca@gmail.com
}

Diajukan 27 Maret 2019 Diperbaiki 14 Mei 2019 Diterima 28 Mei 2019

\section{ABSTRAK}

Latar Belakang: Sepertiga balita mengalami stunting di negara berkembang, $14 \%$ kematian anakanak disebabkan oleh stunting. Pada aspek biologis, tinggi badan ibu penting karena stunting menurun dari kromosom pembawa gen pendek, dan tidak adekuatnya asupan gizi. Dari aspek psikologis, stunting erat kaitannya dengan usia persalinan, peran ganda, dan pola asuh yang tidak memadai. Pola asuh dapat dipengaruhi oleh kepribadian ibu.

Tujuan: Penelitian ini bertujuan melihat korelasi antara tinggi badan ibu, usia persalinan, peran ganda, dan kepribadian ibu terhadap stunting.

Metode: Desain pene;itian kuantitatif dengan pendekatan crosssectional. subjek penelitian diambil dari 110 ibu dari keluarga miskin yang memiliki balita usia 24-59 bulan, dengan teknik simple random sampling. Pengumpulan data usia, peran ganda, dan kepribadian ibu menggunakan kuesioner, untuk variabel tinggi badan ibu dan stunting dengan antropometri menggunakan microtoise.

Hasil: p value untuk badan ibu adalah $0,006(\mathrm{p}<0,05)$ dengan OR 3,606 (CI 95: 1,517-8,572) dan kepribadian ibu dengan nilai $\mathrm{p}$ value $0.035(\mathrm{p}<0,05)$ dengan OR: 0,27 (CI 95:0,086-0,849). Sementara itu, usia persalinan terhadap stunting didapatkan $p$ value $0,99(\mathrm{p}>0,005)$ dan peran ganda terhadap stunting diperoleh $p$ value 0,464 ( $\mathrm{p}>0,005)$.

Kesimpulan: Terdapat signifikansi hubungan tinggi badan ibu dan tipe kepribadian ibu terhadap stunting, sementara itu untuk usia persalinan dan peran ganda tidak berhubungan terhadap kejadian stunting. Disarankan untuk kegiatan penyuluhan kepada masyarakat dilakukan pembaharuan dan modifikasi menyesuaikan tipe kepribadian ibu.

Kata Kunci: stunting; tinggi badan; kepribadian; usia; peran ganda

\section{ABSTRACT}

Background: Stunting incidence in developing countries occurs in one third of children under 5 years, and $14 \%$ of child deaths are caused by stunting. From the biological aspect, mother's height is important because parent's chromosome rear as a determinant of stunting, and the risk can increase if there is inadequate nutritional intake. From the psychological aspect, stunting is closely related to age of labor, double roles of mother, and inadequate parenting. Parenting can be influenced by mother's personality.

Objective: This study aims to discover correlation between biological aspects namely mother's height and psychological aspects, namely age of labor, double roles of mother and mother's personality to stunting.

Method: This study was a quantitative type with a crosssectional approach conducted on 110 mothers from poor families who had children aged 24-59 months who were selected by random sampling. Data collection on age, double roles, and mother's personality using questionnaires, and for variables of mother's height and children's height with measurements using microtoise. Results: Mother's height has p value $0.006(p<0.05)$ with OR 3.606 (CI 95: 1.517-8.572) and mother's personality with $p$ value of 0.035 ( $p<0.05$ ) OR: 0.27 (CI 95: 0.0860.849). Meanwhile, the age of delivery to stunting was obtained $p$ value $0.99(p>0.005)$ and the double role of stunting was obtained p value 0.464 ( $p>0.005)$.

Conclusion: There is a significant correlation among mother's height and mother's personality type to stunting, while for the age of labor and double roles has no related to the incidence of stunting. It is recommended that modifications be made in counseling and providing information to the public according to the mother's personality type.

Keywords: stunting; height; personality; age; double role 


\section{PENDAHULUAN}

Kejadian rendahnya kadar hemoglobin dalam darah, berat badan yang kurang saat lahir, gizi buruk, dan ukuran tinggi/ panjang badan yang tidak sesuai umur menjadi permasalahan gizi yang sering dijumpai di negara berkambang termasuk Indonesia. Kejadian stunting menjadi permasalahan global karena prevalensi yang konsisten tinggi. Terhambatnya pertumbuhan yang menjadi ciri kejadian stunting ditandai dengan kondisi ukuran tinggi badan atau panjang badan dibandingkan umur berada pada angka -2SD (Manary \& Solomon, 2009).

Kondisi gagal tumbuh yang terjadi pada saat balita terbawa hingga remaja dan dewasa. Jika remaja dan dewasa putri mengalami stunting beresiko melahirkan keturunan yang stunting pula (Ricci \& Becker, 1996). Pada daerah dengan tingkat kemiskinan yang tinggi, kejadian stunting umumnya dimulai pada saat balita menginjak usia 6 bulan dan manifestasinya terlihat pada 2-3 tahun kehidupan dan dapat berlanjut hingga usia 18 tahun (Sudirman, 2008). Usia 24-59 bulan merupakan rentang usia dengan prevalensi stunting tertinggi(Ramli et al., 2009).

Suatu kajian dilakukan di kota Bogor oleh Sabaruddin (2012) dan Siswati (2018) mengungkapkan bahwa tinggi badan ibu sangat berkontribusi dalam kejadian stunting, sementara ayah yang memiliki tinggi badan yang pendek tidak berpengaruh terhadap kejadian stunting.

Hurlock (2009) menyatakan bahwa dalam pola asuh orang tua, terdapat beberapa aspek yang berperan, salah satunya yaitu tipe kepribadian orang tua. Orang tua yang satu dan yang lainnya berbeda dalam sikap, kematangan karakter, kesabaran, energi, dan intelegensia. Hal ini berpengaruh terhadap kehandalan orang tua untuk menjalankan tuntutan perannya dalam keluarga, khususnya dalam kepekaan mereka terhadap kebutuhan anak.

Terdapat dua tipe kepribadian pada setiap individu yakni, berkepribadian A dan berkepribadian B. Individu dengan kepribadian A dicirikan dengan sikap yang agresif, jiwa pesaing kuat, orientasi pada hasil, selalu merasa sedikitnya waktu, kesulitan untuk relax, mudah marah dan tidak dapat bersabar jika dihadapkan dengan orang dengan kompetensi rendah atau tidak tepat waktu (Baharudin et al., 2015).

Usia dapat dikategorikan mempengaruhi psikologis pada ibu, utamanya pada saat ibu berada dalam periode hamil dan melahirkan hingga pengasuhan balita. Pengaruh usia ibu terhadap pola pengasuhan anak dapat terjadi secara langsung ataupun tidak langsung. Usia ibu yang masih sangat muda akan mengalami kesulitan dalam persiapan kehamilan, persalinan dan perawatan bayi, di sisi lain ibu yang usianya sudah lanjut (tua), turunnya tingkat energi dalam pengasuhan bayi (Candra et al., 2011).

Keadaan ibu yang memerankan dua lakon dalam kehidupannya yakni, sebagai ibu sekaligus juga sebagai pekerja turut berdampak pada psikologis ibu. Hal ini terkait dengan konflik dan stress pada ibu yang menjalankannya. Data dari Department of Labour United States of America tahun 2019 merilis bahwa 65,1 persen dari wanita yang bekerja memiliki anak berusia di bawah 6 tahun.

Menurut Bower dalam (Reynold, Callender, \& Edward, 2003), tingkat partisipasi ibu pada lapangan kerja utamanya terkait dengan faktor ekonomi, didukung pula oleh faktor demografi, politik dan sosial (Reynold et al., 2003).

Penelitian ini bertujuan untuk mengetahui korelasi antara tipologi biologi dan psikologi ibu terhadap kejadian stunting di Kota Palembang

\section{METODE PENELITIAN}

\section{A. Desain penelitian}

Berdasarkan cara pengambilan data dan analisa data penelitian ini merupakan jenis kuantitatif dengan desain cross-sectional. Responden dalam penelitian ini adalah ibu 
yang memiliki balita usia 24-59 bulan yang dipilih secara acak dari 41 wilayah kerja Puskesmas di Kota Palembang.

B. Variabel dan Definisi Operasional

Variabel dependen dalam penelitian ini adalah kejadian stunting. Variabel ini dapat diketahui dengan cara mengukur tinggi badan balita dari ibu yang menjadi responden dengan menggunakan microtoise dan membandingkan hasilnya dengan tabel pada SK Antropometri tahun 2016 dari Kementrian Kesehatan.

Variabel independen pada penelitian ini adalah tinggi badan ibu, kepribadian ibu, usia persalinan, dan peran ganda. Tinggi badan ibu diukur menggunakan microtoise sedangkan tipe kepribadian, usia ibu, dan peran ganda diketahui dari hasil jawaban responden pada kuesioner.

\section{HASIL}

\section{A. Distribusi Frekuensi}

Distribusi frekuensi karakteristik ibu dan balita dapat dilihat pada tabel 1. Diketahui dari tabel 1, hampir sebagian responden memiliki tinggi badan dibawah $150 \mathrm{~cm}(43,6 \%)$, sebagian besar dengan pendidikan tertinggi hanya sampai tingkat sekolah dasar $(43,6 \%)$, dan persentase ibu yang memainkan peran ganda sebesar 43,6\%. Sebagian besar usia ibu ketika periode persalinan balita yang menjadi subjek penelitian termasuk dalam kelompok usia yang aman untuk hamil dan melahirkan (67,3\%). Dilihat dari segi tipe kepribadiannya, mayoritas responden $(71,8 \%)$ memiliki tipe kepribadian B.

Karakteristik balita yang dapat dilihat pada tabel 1, 32 balita atau $(29,1 \%)$ stunting. Berdasarkan jenis kelamin, responden balita laki-laki lebih banyak dari pada balita perempuan yakni 57 anak laki-laki (51,8\%).
Tabel 1. Distribusi Frekuensi Karakteristik Ibu dan Balita

\begin{tabular}{|c|c|c|}
\hline Variabel & $\mathrm{N}$ & Persentase \\
\hline \multicolumn{3}{|l|}{ Pendidikan Ibu } \\
\hline SD & 48 & 43,6 \\
\hline SMP / sederajat & 25 & 22,7 \\
\hline SMA / sederajat & 36 & 32,7 \\
\hline Diploma & 1 & 0,9 \\
\hline \multicolumn{3}{|l|}{ Status Pekerjaan } \\
\hline Bekerja & 48 & 43,6 \\
\hline Tidak Bekerja & 62 & 56,4 \\
\hline \multicolumn{3}{|l|}{ Tinggi badan Ibu } \\
\hline Pendek (=150 cm) & 48 & 43,6 \\
\hline Normal (>150 cm) & 62 & 56,4 \\
\hline \multicolumn{3}{|l|}{ Tipe Kepribadian Ibu } \\
\hline Tipe A & 31 & 28,2 \\
\hline Tipe B & 79 & 71,8 \\
\hline \multicolumn{3}{|l|}{ Usia Persalinan } \\
\hline Beresiko ( $<20$ tahun atau $>35$ tahun) & 36 & 32,7 \\
\hline Aman & 74 & 67,3 \\
\hline \multicolumn{3}{|l|}{ Peran Ganda } \\
\hline Negatif & 51 & 46,4 \\
\hline Positif & 59 & 54,6 \\
\hline \multicolumn{3}{|l|}{ Kejadian Stunting } \\
\hline Stunting & 32 & 29,1 \\
\hline Normal & 78 & 70,9 \\
\hline \multicolumn{3}{|l|}{ Jenis Kelamin Balita } \\
\hline Laki-laki & 57 & 51,8 \\
\hline Perempuan & 53 & 48,2 \\
\hline
\end{tabular}

B. Hasil Uji Hipotesis

Analisis bivariat menggunakan Chi Squre Test seperti pada tabel 2, terlihat bahwa 21 balita atau $43,8 \%$ balita yang stunting dilahirkan oleh ibu dengan tinggi badan yang pendek. Berdasarkan hasil uji statistik diputuskan untuk menolak $\mathrm{H}_{\alpha}$ artinya terdapat keterkaitan tinggi badan ibu dengan kejadian stunting dengan p value $0.003(p<0.05)$.

Analisis bivariat dengan Chi Squre Test menunjukkan bahwa $64,6 \%$ atau 51 balita yang tidak stunting merupakan anak dari ibu berkepribadian B. Berdasarkan uji Chi Square test diputuskan $\mathrm{H}_{\mathrm{o}}$ ditolak, yang maknanya terdapat hubungan antara tipe kepribadian ibu dengan kejadian stunting dengan $\mathrm{p}$ value 0,035 $(\mathrm{p}<0,05)$.

Analisis bivariat dengan Chi Squre Test seperti pada tabel 2 , menyatakan bahwa nilai $p$ value untuk variabel peran ganda adalah 0,464 $(\mathrm{p}>0,05)$, sehingga Ho diterima yang artinya secara statistik tidak terdapat hubungan antara peran ganda dengan kejadian stunting.

Terlihat pada tabel 2 usia persalinan 
dengan nilai $\mathrm{p}$ value 0,99 ( $\mathrm{p}>0.05$ ), sehingga Ho diterima maknanya tidak terdapat hubungan antara peran ganda dengan kejadian stunting.

Tabel 2. Hasil Analisis Bivariat dengan Chi Square Test

\begin{tabular}{ccccccccc}
\hline & \multicolumn{4}{c}{ Stunting } & \multicolumn{2}{c}{ Total } & OR & \multirow{2}{*}{ P value } \\
Variabel & \multicolumn{2}{c}{ Ya } & \multicolumn{2}{c}{ Tidak } & \multicolumn{2}{c}{ (95) } & \\
& $\mathrm{n}$ & $\%$ & $\mathrm{n}$ & $\%$ & $\mathrm{n}$ & $\%$ & & \\
\hline Tinggi Badan Ibu & & & & & & & & \\
$\quad$ Pendek & 21 & 43,8 & 27 & 56,2 & 48 & 100 & $3,606(1,517-8,572)$ & 0,006 \\
$\quad$ Normal & 11 & 17,7 & 51 & 82,3 & 62 & 100 & & \\
Tipe Kepribadian & & & & & & & & \\
$\quad$ Ibu & & & & & & & & \\
$\quad$ Tipe A & 4 & 12,9 & 27 & 89,1 & 31 & 100 & $0,27(0,086-0,849)$ & 0,035 \\
$\quad$ Tipe B & 28 & 35,4 & 51 & 64,6 & 79 & 100 & & \\
Peran Ganda & & & & & & & & \\
$\quad$ Negatif & 17 & 33,3 & 34 & 66,7 & 51 & 100 & 1,467 & \\
$\quad$ Positif & 15 & 25,4 & 44 & 74,6 & 59 & 100 & & \\
Usia Persalinan & & & & & & & & \\
$\quad$ Beresiko & 11 & 30,6 & 25 & 69,4 & 36 & 100 & 1,11 & 0,990 \\
$\quad$ Aman & 21 & 28,4 & 53 & 71,6 & 74 & 100 & & \\
\hline
\end{tabular}

\section{PEMBAHASAN}

Diketahui dari tabel 2 korelasi yang dapat dijelaskan dari hasil uji statistik tersebuta yaitu, ibu yang bertubuh pendek kurang dari $150 \mathrm{~cm}$ berisiko melahirkan anak stunting sebesar 3,6 kali (CI 95; 1,517-8,572) dibaningkan ibu berbadan tinggi / normal (lebih dari $150 \mathrm{~cm}$ ).

Linier dengan riset (Rochmah, 2017) diketahui kecenderungan ibu berbadan pendek untuk memiliki anak yang stunting adalah sebesar 10,1 kali dibandingkan ibu dengan tinggi badan normal.

Menurut(Eka Kusuma \& Nuryanto, 2013) bahwa sifat pendek yang diturunkan orang tua kepada anaknya dikarenakan kondisi tinggi badan mereka yang tergolong pendek juga. Disebabkan terjadinya suatu keadaan patologis pada kromosom dalam inti sel, akibat kekurangan hormon pertumbuhan. Diperberat dengan konsumsi zat gizi yang tidak adekuat dalam mendukung pertumbuhan sehingga akan berdampak pada kegagalan pertumbuhan atau stunting pada keturunan berikutnya.

Dilihat dari tabel 2, ibu berkepribadian A berisiko memiliki anak yang stunting sebanyak 0,27 kali (CI 95; 0,086-0,849) dibandingkan dengan ibu berkepribadian B. Berdasarkan penelitian yang dilakukan oleh (Adawiyah,
2017), perbedaan kepribadian orang tua menyebabkan perbedaan tingkatan pada kematangan sikap, kesabaran, intelegensi dan energi. Karakteristik tersebut berpengaruh pada mumpuninya orang tua untuk peka terhadap kebutuhan anaknya.

Seorang ibu dengan kepribadian A yang lebih menyukai menyelesaikan semua pekerjaan dalam sekali waktu, berimbas pada proses pemberian makan pada anak. Ibu terburu-buru dalam proses feeding. Hal ini tentu akan mengganggu kenyamanan anak dalam menghabiskan makanannya sehingga sang anak tidak menghabiskannya. Hal ini menjadi potensi bahaya untuk terjadinya stunting jika berlangsung terus menerus. Anak tidak menghabiskan makanannya sehingga tidak terjadi peningkatan kuantitas maupun kualitas makanan anak, ditambah jika makanan tersebut tidak adekuatnya zat gizi.

Pada penelitian ini, usia persalinan tidak bermakna secara statistik dengan kejadian stunting karena tidak munculnya masalah psikologis pada para ibu, umunya mereka melakukan persalinan pada kelompok usia aman untuk hamil dan melahirkan. Hasil dari penelitian ini, peran ganda tidak berhubungan dengan kejadian stunting karena baik ibu bekerja maupun ibu rumah tangga tetap 
memperhatikan balitanya, baik itu dititipkan kepada orang tua atau membawa anak ikut serta.

\section{KESIMPULAN DAN SARAN}

Hasil penelitian ini dapat disimpulkan bahwa tinggi badan dan kepribadian ibu merupakan faktor yang berhubungan dengan kejadian stunting pada keluarga miskin di kota Palembang. Oleh karena itu, perlu dilakukan pencegahan dini terhadap stunting, salah satunya dengan memberikan perhatian dan edukasi tentang pentingya konsumsi zat gizi yang adekuat khususnya pada ibu hamil dengan tinggi badan yang pendek ( $\leq 150 \mathrm{~cm})$.

Proses penyampaian penyuluhan atau informasi kepada ibu, perlu dilakukan modifikasi sesuai dengan tipe kepribadian ibu yang dapat terlihat secara visual.

\section{DAFTAR PUSTAKA}

Adawiyah, R. (2017). Pola Asuh Orang Tua dan Implikasinya Terhadap Anak (Studi pada Masyarakat Dayak di Kecamatan Halong Kabupaten Balangan). Jurnal Pendidikan Kewarganegaraan, 7(1).

Baharudin, B., Nuraini Kurdi, F., \& Lionardo, A. (2015). Analisis Perbedaan Tipe Kepribadian A Dan B Terhadap Manajemen Konflik Interpersonal Pada Pegawai Rumah Sakit Khusus Mata Provinsi Sumatera Selatan. Jurnal Psikologi Islam. 1(2): 25-33. Retrieved from http://jurnal.radenfatah.ac.id/ index.php/psikis/article/view/565\%0A

Candra, A., Puruhita, N., \& Susanto, J. (2011).

Risk Factors Of Stunting Among 1-2 Years

Old Children In Semarang City. Media Medika Indonesiana. 45(3).

Eka Kusuma, K., \& Nuryanto. (2013). Faktor Risiko Kejadian Stunting Pada Anak Usia 2 - 3 Tahun di Kecamatan Semarang Timur. Journal of Nutrition College. 2(4):523-530. https://doi.org/ https://doi.org/10.14710/jnc.v2i4.3735

Hurlock, E. B. (2009). Psikologi Perkembangan: Suatu Pendekatan Sepanjang Rentang
Kehidupan. (R. M. Sijabat, Ed.) (5th ed.). Jakarta: Erlangga.

Manary, M. ., \& Solomon, N. . (2009). Public Health Nutrition, Nutrition and Child Development. In M. J. Gibney, B. M. Margetts, J. M. Kearney, \& L. Arab (Eds.), Public Health Nutrition. United Kingdom: Blackwell Publishing.

Ramli, E Agho, K., J Inder, K., J Bowe, S., Jennifer, J., \& J Dibley, M. (2009). Prevalence and Risk factors for Stunting and severe Stunting among under fives in North Maluku Province of Indonesia. B M C Pediatrics . 9 (1): 64 . https://doi.org/https://doi.org/10.1186/14 71-2431-9-64

Reynold, T., Callender, C., \& Edward, R. (2003). Caring and Counting: The Impact of Mothers' Employment on Family Relationship. United Kingdom: The Policy Press.

Ricci, J., \& Becker, S. (1996). Risk factors for wasting and stunting among children in Metro Cebu, Philippines. The American Journal of Clinical Nutrition 63(6): 966975 https://doi.org/10.1093/ajcn/63.6.966

Rochmah, A. M. (2017). Faktor-Faktor yang Berhubungan dengan Stunting Pada Balita Usia 24-59 Bulan di Wilayah Kerja Puskesmas Wonosari I. Universitas 'Aisyiyah Yogyakarya. Retrieved from http://digilib.unisayogya.ac.id/id/eprint/ 2535

Sabaruddin, E. E. (2012). Kajian Positive Deviance Masalah Stunting Balita Pada Keluarga Miskin di Kota Bogor. Institut Pertanian Bogor.

Siswati, T. (2018). Determinan Sosial, Struktural Dan Biologi Kejadian Stunting Balita Di Indonesia. Universitas Gadjah Mada.

Sudirman, H. (2008). Stunting atau Pendek : Awal Perubahan Patologis atau Adaptasi karena Perubahan Sosial Ekonomi yang Berkepanjangan. Media Penelitian Dan Pengembangan Kesehatan, 18. 